\title{
Vitamin B12 and homocysteine levels in patients with NAFLD: a systematic review and metanalysis
}

\author{
Débora Silva COSTA ${ }^{1}$, Marina P GUAHNON ${ }^{1}$, Fernanda Braga SEGANFRED0², Letícia P PINTO \\ Cristiane V TOVO ${ }^{3}$ and Sabrina Alves FERNANDES ${ }^{1}$
}

Received: 9 September 2020 Accepted: 16 November 2020

\begin{abstract}
Background - The vitamin B12 absorption can be affected in patients with nonalcoholic fatty liver disease (NAFLD), and low serum vitamin B12 levels has been related to the high homocysteine (HCY) levels and to the degree of NAFLD. Objective - To carry out a systematic review and metanalysis of serum vitamin B12 and HCY levels in patients with NAFLD. Methods - Original studies including serum vitamin B12 and HCY levels in humans with NAFLD were included. The searches were performed in four databases. Results -159 studies were identified, and after excluding the duplicates and non-eligible titles, eight original articles were included. Six out of eight showed higher B12 levels in NAFLD patients (404.9 \pm 136.2 pg/ $\mathrm{mL}$ in relation to controls $353.91 \pm 117.3 \mathrm{pg} / \mathrm{mL}$ ). Seven of the eight studies also showed higher HCY levels in NAFLD patients (14.2 $\pm 3.44 \mathrm{umol} / \mathrm{L}$ in relation to controls $11.05 \pm 3.6 \mathrm{umol} / \mathrm{L}$ ). The results for serum vitamin B12 and HCY levels were submitted to metanalysis, showing no difference in the vitamin B12 levels between patients with NAFLD and controls. However, the levels of Hcy were higher in NAFLD patients than in controls. Conclusion - There was no relashionship between the vitamin B12 levels and NAFLD. The levels of HCY were significantly higher in patients with NAFLD, suggesting this could be a potential marker for liver damage.
\end{abstract}

Keywords - Non-alcoholic fatty liver disease; non-alcoholic steatohepatitis; vitamin B12; vitamins; homocysteine.

\section{INTRODUCTION}

Nonalcoholic fatty liver disease (NAFLD) is defined by the accumulation of triglycerides in more than $5 \%$ of hepatocytes and the absence of secondary causes such as significant alcohol consumption ( $>20 \mathrm{~g}$ for women and $>30 \mathrm{~g}$ for men daily), use of potentially steatogenic medications or hereditary disorders, and is commonly associated with metabolic comorbidities such as obesity, insulin resistance (IR) / type 2 diabetes mellitus (DM2) and dyslipidemia ${ }^{(1)}$. Recently, an international consensus proposed a new definition for the diagnosis of the now called metabolic associated fatty liver disease (MAFLD), stablishing "positive criteria" based on the evidence of hepatic steatosis and one of the following three criteria, namely overweight/obesity, presence of DM2, or evidence of metabolic dysregulation, independent of other liver diseases ${ }^{(2)}$.

The pathogenesis of NAFLD is complex and multifactorial. Eating habits with excessive consumption of processed foods and high consumption of sugary drinks, associated with environmental and genetic factors can lead to IR, obesity and changes in the intestinal microbiota ${ }^{(3)}$. These factors directly interfere with liver metabolism, inhibiting fatty acid oxidation, reflecting decreased uptake and utilization of glucose, generating IR and consequently production of reactive oxygen species (EROS) in the liver, stimulating the production of tumor necrosis factor alpha $(\mathrm{TNF}-\alpha)^{(4)}$. The damage caused by EROS not only inactivates the metabolites and structures from macronutrients, but promotes vitamin deficiency, being the vitamin B12 absorption the most affected. Low serum vitamin B12 levels has been related to patients with NAFLD, and to the degree of NAFLD activity and fibrosis ${ }^{(5)}$. Patients with chronic liver disease can benefit from this vitamin, since its antioxidant effect has postulated hepatoprotective function and, therefore, the importance of understanding the relationship of serum levels of this vitamin in patients with NAFLD ${ }^{(4)}$. Low levels of vitamin B12 have been linked to high levels of homocysteine (HCY) characterizing hyperhomocysteinemia as an indicator of oxidative stress ${ }^{(4)}$.

This study has as its main objective to conduct a systematic review and metanalysis of serum vitamin B12 and HCY levels in NAFLD patients and their staging.

\section{METHODS}

The search was carried out for publications on bases up to August 2020. The databases were PubMed, Lilacs, Embase and SciELO. The studies were located based on the definition of a search strategy and selected according to predefined criteria after reading by two independent reviewers; doubt cases were evaluated by a third reviewer.

\section{Search strategy}

The search strategy used to locate the publications was based on entering the English terms for vitamin B12: "B 12, vitamin" [MeSH] OR "vitamin B12" OR "B12, vitamin" OR "cyanocobalamin" OR "cobalamins" OR "cobalamin" OR "eritron"; for homocysteine: "homocysteine" [MeSH] OR "2-amino-4-mercaptobutyric 
acid" OR "2 amino 4 mercaptobutyric acid" OR "homocysteine, L-Isomer" OR "homocysteine, L Isomer" OR "L-isomer homocysteine"; for NAFLD: "nonalcoholic fatty liver disease" [MeSH] OR "NAFLD" OR "nonalcoholic fatty liver disease" OR "fatty liver, nonalcoholic" OR "fatty livers, nonalcoholic" OR "liver, nonalcoholic fatty" OR "livers, nonalcoholic fatty" OR "nonalcoholic fatty liver" OR "nonalcoholic fatty livers" OR "nonalcoholic steatohepatitis" OR "Nonalcoholic steatohepatitides" OR "steatohepatitides, nonalcoholic" OR "steatohepatitis, nonalcoholic"; and the combinations.

\section{Elegibility criteria}

Studies evaluating serum vitamin B12 and HCY levels in adults diagnosed with NAFLD were included. Studies whose research designs comprised revision studies, case reports, experimental studies or evaluating children were excluded. The articles were not limited as to the year of publication nor to language due to the scarcity of publications on the subject.

\section{Analysis}

Random models were analyzed using crude mean difference as the measure of effect. Calculation was obtained by the mean of the exposed group - mean of the control group.

\section{Risk of bias}

The risk of bias was assessment for non-randomized studies based on the Risk of Bias Assessment tool for Non-randomized Studies'criteria (RoBANS).

\section{RESULTS}

Overall, 37 studies were identified, and after excluding the duplicates and non-eligible titles, eight original articles were included ${ }^{(6-13)}$. A detailed flowchart showing the study selection process is presented in FIGURE 1. The inter-rater agreement, as calculated by Cohen's kappa coefficient was 0.9 .

The general characteristics of the eight included studies are described in TABLE 1. All the eight studies evaluated B12 levels, HCY and compared NAFLD patients with controls. One study divided patients in having NAFLD and nonalcoholic steatohepatitis (NASH) $)^{(10)}$.

All studies used healthy individuals as controls, and one of them added a chronic viral hepatitis as a second control ${ }^{(13)}$. All the eight studies had a cross-sectional design. All studies were published between the years 2005 and 2019. The number of included patients varied between 17 and 1358 patients.

The main characteristics of the included patients are presented in TABLE 2. All studies included both genders, with a predominance of women, and the average age varied between 39 and 54 years. The average BMI of the included patients was $38.31 \pm 3.64 \mathrm{~kg} /$ $\mathrm{m}^{2}$. Six out of eight showed a higher B12 level in NAFLD patients (mean 223.5 to $473.1 \mathrm{pg} / \mathrm{mL}$ ) when compared to controls (mean 171.9 to $448.0 \mathrm{pg} / \mathrm{mL}$ ). Seven out of eight studies presented higher HCY levels in NAFLD patients (mean 9.18 to 56.3 umol/L) when compared to controls (mean 8.49 to 19.7 umol/L).

The results for serum vitamin B12 and HCY levels were submitted to metanalysis (FIGURE 2 and 3 respectively), showing that it

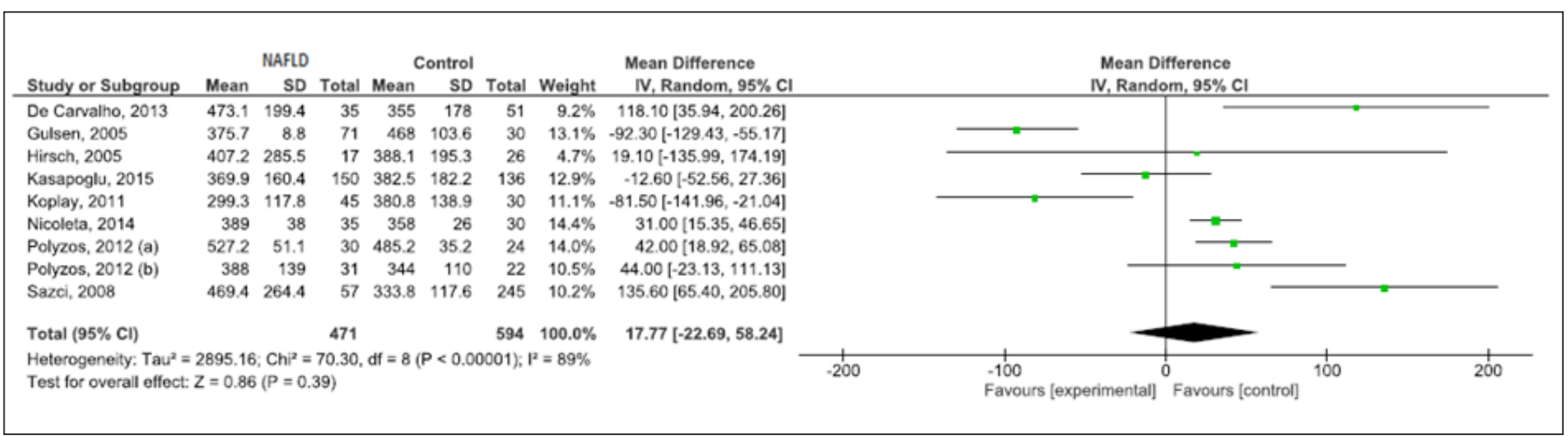

FIGURE 1. Vitamin B12 levels in patients with nonalcoholic fatty liver disease, metanalysis.

TABLE 1. Characteristics of the included studies.

\begin{tabular}{|c|c|c|c|}
\hline Author / year & Purpose & Design & $\mathbf{N}$ \\
\hline Moretti, $2019^{(8)}$ & $\begin{array}{l}\text { To find a relationship between some vascular risk factors, such as lack of folate, vitamin B12, } \\
\text { vitamin D and increased levels of homocysteine with cognitive and behavioral changes in } \\
\text { patients with NAFLD }\end{array}$ & Cross-sectional & 1358 \\
\hline Leach N, 2014 (9) & $\begin{array}{l}\text { To investigate homocysteine and oxidative stress in NAFLD, and the association with } \\
\text { cardiovascular disease. }\end{array}$ & Cross-sectional & 35 \\
\hline Gulsen, 2005(12) & To evaluate seric levels of homocysteine in patients with NASH & Cross-sectional & 71 \\
\hline De Carvalho, $2013^{(13)}$ & $\begin{array}{l}\text { To investigate the relation between homocysteine levels and MTHFR C677T polimorfisms in } \\
\text { patients with NAFLD }\end{array}$ & Cross-sectional & 35 \\
\hline
\end{tabular}

NAFLD: nonalcoholic fatty liver disease. 
TABLE 2. Characteristics of the included studies.

\begin{tabular}{|c|c|c|c|c|c|}
\hline Aurhor / year & Gender & Age & BMI & Vitamin B12 & Homocysteine \\
\hline Saczi, $2008^{(6)}$ & $\begin{array}{c}\text { NAFLD } 45.05 \\
\text { CONTROL } 43.32\end{array}$ & $\begin{array}{c}\text { NAFLD } 44.25 \pm 5.85 \\
\text { CONTROL } \\
44.73 \pm 5.15\end{array}$ & $25.62 \pm 3.8$ & $\begin{array}{c}\text { NAFLD } 469.45 \pm 264.4 \\
\text { CONTROL } \\
333.8 \pm 117.6\end{array}$ & $\begin{array}{l}\text { NAFLD } 13.2 \pm 7.42 \\
\text { CONTROL } 10.48 \pm 3\end{array}$ \\
\hline Polyzos, $2012^{(7)}$ & $\begin{array}{l}\text { NAFLD } 74.2 \\
\text { CONTROL } 68.6\end{array}$ & $\begin{array}{l}\text { NAFLD } 54 \pm 11 \\
\text { CONTROL } 52 \pm 9\end{array}$ & $30.7 \pm 3.8$ & $\begin{array}{c}\text { NAFLD } 388 \pm 139 \\
\text { CONTROL } \\
344.0 \pm 110.0\end{array}$ & $\begin{array}{c}\text { NAFLD } 13.5 \pm 2.6 \\
\text { CONTROL } 12.6 \pm 4.6\end{array}$ \\
\hline Moretti, $2019^{(8)}$ & $\begin{array}{l}\text { NAFLD } 45.5 \\
\text { CONTROL } 46.1\end{array}$ & $\begin{array}{c}\text { NAFLD } 56 \pm 1.6 \\
\text { CONTROL } 59.1 \pm 1.4\end{array}$ & $\begin{array}{c}\text { NAFLD } \\
<25: 103(15.9) \\
25-29.9: 210(32.4) \\
\geq 30: 334(51.6) \\
\text { CONTROL } \\
<25: 209(32.0) \\
25-29.9: 284(43.3) \\
\geq 30: 160(24.5)\end{array}$ & $\begin{array}{c}\text { NAFLD } 353.3 \pm 45.3 \\
\text { CONTROL } \\
237.2 \pm 12.5\end{array}$ & $\begin{array}{c}\text { NAFLD } 56.3 \pm 8.5 \\
\text { CONTROL } 19.7 \pm 3.4\end{array}$ \\
\hline Leach, $2014^{(9)}$ & NAFLD 42.9 & $\begin{array}{c}\text { NAFLD } 45.7 \pm 10.9 \\
\text { CONTROL } 44.9 \pm 7.7\end{array}$ & $22.8 \pm 3.6$ & $\begin{array}{c}\text { NAFLD 223.5 } \\
\text { CONTROL } 171.9\end{array}$ & $\begin{array}{l}\text { NAFLD } 12.7 \pm 3.4 \\
\text { CONTROL } 9.95 \pm 2\end{array}$ \\
\hline Kasapogl, $2015^{(10)}$ & $\begin{array}{c}\text { NAFLD } 70.3 \\
\text { CONTROL } 69.1\end{array}$ & $\begin{array}{c}\text { NAFLD } 49.4 \pm 11.3 \\
\text { CONTROL } 45.8 \pm 14.9\end{array}$ & $28.4 \pm 3.1$ & $\begin{array}{c}\text { NAFLD } 369.9 \pm 160.4 \\
\text { CONTROL } \\
382.5 \pm 182.2\end{array}$ & $\begin{array}{c}\text { NAFLD } 19.2 \pm 2.7 \\
\text { CONTROL } 15.7 \pm 8.4\end{array}$ \\
\hline Hirsch, $2005^{(11)}$ & $\begin{array}{l}\text { NAFLD } 100 \\
\text { CONTROL } 100\end{array}$ & $\begin{array}{c}\text { NAFLD } 37.4 \pm 12.3 \\
\text { CONTROL } 42.2 \pm 11.0\end{array}$ & $41.3 \pm 5.3$ & $\begin{array}{c}\text { NAFLD } 407.2 \pm 285.5 \\
\text { CONTROL } \\
388.1 \pm 195.3\end{array}$ & $\begin{array}{l}\text { NAFLD } 9.18 \pm 2.40 \\
\text { CONTROL } 9.65 \pm 3.91\end{array}$ \\
\hline
\end{tabular}

Units: Gender (\% females); Age (average $\pm \mathrm{SD}$; years); BMI (average $\pm \mathrm{SD} ; \mathrm{kg} / \mathrm{m}^{2}$ or n (\%); Vitamin B12 (average $\pm \mathrm{SD}$; pg/mL); Homocysteine (average $\left.\pm \mathrm{SD} ; \mathrm{mmol} / \mathrm{L}\right) ;$ Folate (average $\pm \mathrm{SD}$ $\mathrm{ng} / \mathrm{mL})$. NAFLD: nonalcoholic fatty liver disease.

\begin{tabular}{|c|c|c|c|c|c|c|c|c|c|c|}
\hline \multirow[b]{2}{*}{ Study or Subgroup } & \multicolumn{3}{|c|}{ NAFLD } & \multicolumn{3}{|c|}{ Control } & \multirow[b]{2}{*}{ Weight } & \multirow{2}{*}{$\begin{array}{l}\text { Mean Difference } \\
\text { IV, Random, } 95 \% \mathrm{CI}\end{array}$} & \multirow{2}{*}{\multicolumn{2}{|c|}{$\begin{array}{c}\text { Mean Difference } \\
\text { IV, Random, } 95 \% \mathrm{Cl}\end{array}$}} \\
\hline & Mean & SD & Total & Mean & SD & Total & & & & \\
\hline De Carvalho, 2013 & 9.6 & 2.8 & 35 & 8.4 & 1.7 & 51 & $19.6 \%$ & $1.20[0.16,2.24]$ & & \\
\hline Gulsen, 2005 & 13.7 & 2.6 & 71 & 10.5 & 1.5 & 30 & $20.8 \%$ & $3.20[2.39,4.01]$ & & \\
\hline Hirsch, 2005 & 9.1 & 2.4 & 17 & 9.6 & 3.9 & 26 & $14.7 \%$ & $-0.50[-2.38,1.38]$ & & \\
\hline Kasapoglu, 2015 & 19.2 & 2.7 & 150 & 15.7 & 8.4 & 136 & $17.1 \%$ & $3.50[2.02,4.98]$ & & \\
\hline Polyzos, 2012 (b) & 13.5 & 2.6 & 31 & 12.6 & 4.6 & 22 & $13.4 \%$ & $0.90[-1.23,3.03]$ & & \\
\hline Sazci, 2008 & 13.2 & 7.4 & 57 & 10.4 & 3 & 245 & $14.3 \%$ & $2.80[0.84,4.76]$ & & \\
\hline Total $(95 \% \mathrm{CI})$ & & & 361 & & & 510 & $100.0 \%$ & $1.95[0.74,3.15]$ & & \\
\hline \multicolumn{9}{|c|}{ Heterogeneity: Tau $^{2}=1.64 ; \mathrm{Chi}^{2}=22.00, \mathrm{df}=5(\mathrm{P}=0.0005) ; \mathrm{I}^{2}=77 \%$} & $\begin{array}{cc}1 & 1 \\
-4 & -2 \\
\text { Favours [experimental] }\end{array}$ & \begin{tabular}{|c|c|} 
& 1 \\
0 & 2 \\
Favours [control]
\end{tabular} \\
\hline
\end{tabular}

FIGURE 2. Homocysteine levels in patients with nonalcoholic fatty liver disease, metanalysis. 


\begin{tabular}{|c|c|c|c|c|c|c|}
\hline & $\begin{array}{c}\text { Selection } \\
\text { of } \\
\text { patients }\end{array}$ & $\begin{array}{l}\text { Confounding } \\
\text { variables }\end{array}$ & $\begin{array}{l}\text { Measurement } \\
\text { of exposure }\end{array}$ & $\begin{array}{c}\text { Blinding } \\
\text { of } \\
\text { outcomes }\end{array}$ & $\begin{array}{c}\text { Incomplete } \\
\text { outcome } \\
\text { data }\end{array}$ & $\begin{array}{l}\text { Selective } \\
\text { Reporting }\end{array}$ \\
\hline $\begin{array}{l}\text { Kasapoglu } \\
\text { B, et al, } \\
2015^{5} \\
\end{array}$ & $\oplus$ & $?$ & $?$ & 4 & & \\
\hline $\begin{array}{c}\text { De } \\
\text { Carvalho } \\
\text { SC, et al, } \\
2013^{6}\end{array}$ & & & & & & $?$ \\
\hline $\begin{array}{c}\text { Polyzos } \\
\text { AS, et al, } \\
2012^{7}\end{array}$ & & & & & & \\
\hline $\begin{array}{l}\text { Koplay M, } \\
\text { et al., } \\
2011^{8} \\
\end{array}$ & $\oplus$ & 4 & & & & \\
\hline $\begin{array}{c}\text { Sazci } A, \text { et } \\
a l, 2008^{9}\end{array}$ & & + & & & & \\
\hline $\begin{array}{l}\text { Gulsen } M \text {, } \\
\text { et al, } \\
2005^{10}\end{array}$ & & $?$ & & & & \\
\hline $\begin{array}{l}\text { Hirsch S, } \\
\text { et al., } \\
2005^{11} \\
\end{array}$ & & + & & & + & \\
\hline $\begin{array}{c}\text { Polyzos } \\
\text { AS, et al., } \\
2012^{12}\end{array}$ & & + & + & & & \\
\hline $\begin{array}{l}\text { Leach } N \text {, et } \\
\text { al., 2014 }\end{array}$ & $\oplus$ & & & & + & \\
\hline
\end{tabular}

FIGURE 3. Risk of bias assessment for non-randomized studies based on the Risk of Bias Assessment tool for Non-randomized Studies'criteria (RoBANS).

is not possible to state that patients with liver disease have different vitamin B12 levels than controls. However, patients with liver disease have higher HCY levels than controls. The studies presented a high heterogeneity ( $89 \%$ for vitamin B12 and 77\% for HCY).

When the risk of bias was assessed, the selection of participants was described in all; confounding variables was not well described in three studies ${ }^{(8,10,12)}$, the measurement of exposure in two ${ }^{(8,10)}$, the blinding of outcomes was described in all, incomplete outcome data in one ${ }^{(8)}$ and selective reporting in one ${ }^{(13)}$ (FIGURE 4).

\section{DISCUSSION}

There are relatively few studies evaluating the serum levels of HCY in patients with NAFLD and NASH, showing contradictory results. The study of Leach $\mathrm{NV}$ et al. ${ }^{(14)}$, showed a high level of $\mathrm{HCY}$ in NASH patients when compared to controls $(12.73 \pm 3.43$ $\mu \mathrm{mol} / \mathrm{L}$ vs $9.95 \pm 2 \mu \mathrm{mol} / \mathrm{L} ; P=0.001)$ and it was not caused by the deficiency of cofactors (the levels of the vitamins B6, B12 and folic acid were similar in both groups). These data are consistent with the metanalysis of Yining Dai et al. ${ }^{(15)}$, that found eight studies totaling 935 participants (397 NAFLD cases and 538 controls), that evaluated the serum HCY levels and/or the levels of HCY -related vitamins. They found that NAFLD patients presented increased levels of HCY, although the levels of HCY -related vitamins were not statistically significantly different comparing with controls $(P=0.342)$. On the other hand, Polyzos et al. ${ }^{(7,16)}$ have reported that HCY levels were similar in NAFLD patients and control.

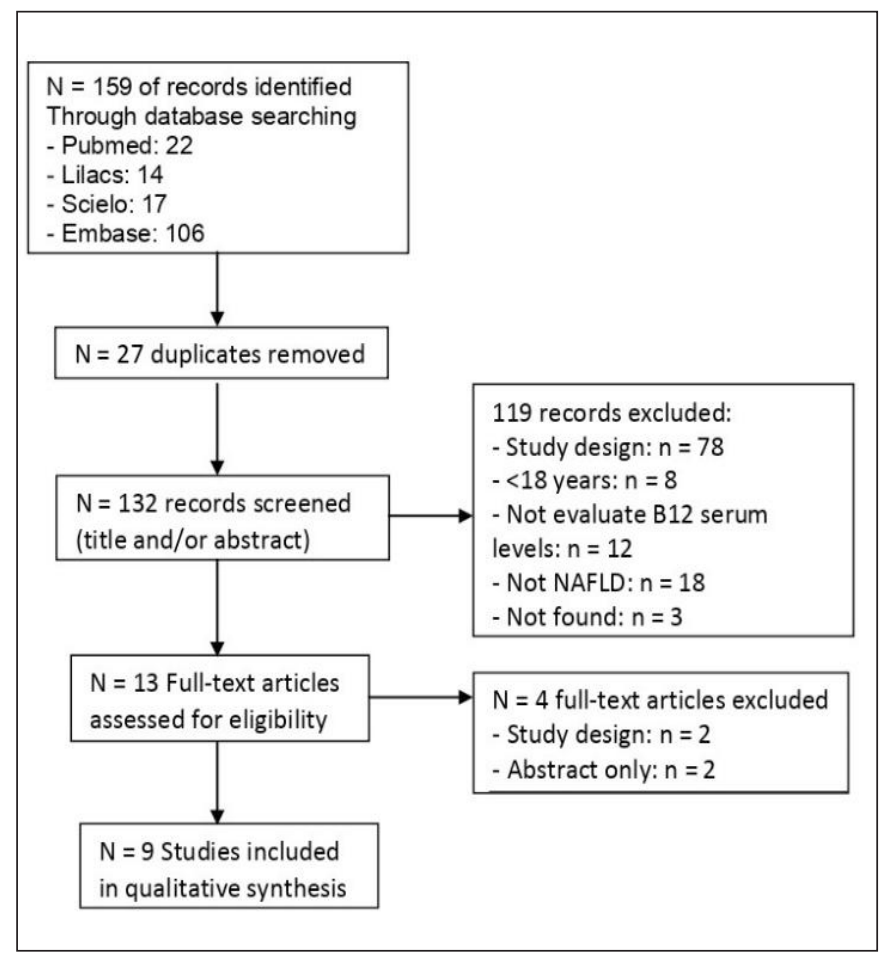

FIGURE 4. Flowchart of study selection.

A relationship between liver diseases and serum vitamin B12 levels has been proposed ${ }^{(17)}$. However, the present systematic review and metanalysis found eight studies ${ }^{(6-13)}$ evaluating vitamin B12 levels and HCY in NAFLD patients, and showed no relashionship between vitamin B12 levels and NAFLD. On the other hand, when the levels of HCY were metanalysed, it was observed higher values in patients with NAFLD.

One of the studies evaluated 45 consecutive patients with NAFLD and 30 healthy controls. The authors concluded that the serum vitamin B12 levels were significantly lower in the patients with NAFLD than in those of the control group, though still remaining in the reference range. Consequently, low vitamin B12 levels should be associated with NAFLD, especially in grade 2 to grade 3 hepatosteatosis ${ }^{(17)}$.

On the other side, another authors evaluated 57 NASH patients and 245 healthy controls, showing controvertial results. The serum levels of vitamin B12 were significantly lower in control patients than in those with NAFLD $(246.33 \pm 86.89 \mathrm{pmol} / \mathrm{L}$ vs $346.37 \pm 195.10 \mathrm{pmol} / \mathrm{L} ; P=0.022)^{(6)}$.

Genetic mutations observed in folate metabolism may result in increased HCY levels. It has been reported that increased serum HCY levels may affect the intracellular fat metabolism causing enhanced fatty infiltration in the liver resulting, in NAFLD. However, there are no satisfactory data on HCY concentrations in patients with NAFLD ${ }^{(10)}$.

The study of Gulsen $\mathrm{M}$ et al. ${ }^{(12)}$ evaluated the clinical significance of plasma HCY concentrations in 71 patients with NAFLD and 30 healthy controls, showing that the HCY levels in the NAFLD group was significantly higher than in controls, and was especially higher in the NASH patients when compared with those with simple steatosis. Also, a negative correlation was found between HCY and folate or vitamin B12. 
The study of Kasapoglu B et al. ${ }^{(10)}$ evaluated 150 patients with NAFLD and 136 healthy controls without NAFLD. Although there was no significant difference in vitamin B12 and folic acid serum levels, HCY levels were significantly higher in the more severe disease than that of control and mild groups $(P<0.001)$.

A Brazilian study evaluated 35 patients with NAFLD by liver biopsy and 45 healthy controls, observing that the plasma HCY levels was higher in NAFLD patients compared to the control group $(P=0.0341)$. Also, a negative correlation was observed between levels of vitamin B12 and HCY concentration $(P=0.005)^{(13)}$.

The study of Hisrsch $\mathrm{S}$ et al. ${ }^{(11)}$ investigated 43 obese patients who underwent bariatric surgery, observing and similar concentrations of serum HCY and vitamin B12 in both groups.

Other authors ${ }^{(18)}$ evaluated serum vitamin B12 levels in 30 patients with biopsy-proven NAFLD and their association with the disease severity, relating similar vitamin B12 levels in non-NASH and NAFLD patients, and also in controls.

The same group ${ }^{(7)}$ evaluated the serum HCY levels in 31 patients with NAFLD and 22 healthy controls. There was no difference in mean serum HCY levels between controls and NAFLD patients (12.6 \pm 4.6 vs $13.5 \pm 2.6 \mathrm{mmol} / \mathrm{L}$, respectively; $P=0.432)$. Serum vitamin B12 were also similar between the study groups. However, NASH patients had lower mean serum HCY levels when compared to NAFLD patients $(12.3 \pm 2.5$ vs $14.7 \pm 2.1 \mathrm{mmol} / \mathrm{L} ; P=0.006)$. HCY independently predicted NASH $(P=0.045)$, and the data suggested that serum HCY levels are lower in NASH compared with NAFLD patients and can independently predict NASH.

In the same way, the serum HCY levels and oxidative stress were evaluated in 50 patients with NASH and 30 healthy controls. No differences in vitamin B12 levels was observed ${ }^{(18)}$.
When the risk of bias was assessed, the selection of participants was described in all; confounding variables was not well described in three studies ${ }^{(8,10,12)}$, the measurement of exposure in two $^{(8,10)}$, the blinding of outcomes was described in all, incomplete outcome data in one ${ }^{(8)}$ and selective reporting in one ${ }^{(13)}$. Also, a great heterogeneity in the metanalysed studies was observed.

\section{CONCLUSION}

In conclusion, the present systematic review and metanalysis showed no relashionship between vitamin B12 levels and NAFLD. On the other side, the levels of HCY were significantly higher in patients with NAFLD, suggesting this could be a potential marker for liver damage.

\section{Authors' contribution}

Conceptualization: Fernandes AS. Data collection and review of the formal analysis of the databases: Costa DS, Guahnon MP and Seganfredo FB. Original preparation of the manuscript: Pinto LP, Fernandes AS, Tovo CV. All authors read and agreed to the published version of the manuscript.

\section{Orcid}

Débora Silva Costa: 0000-0002-2560-3591.

Marina Guahnon: 0000-0003-2178-314X.

Fernanda Braga Seganfredo: 0000-0003-1495-9776.

Letícia Pereira Pinto: 0000-0001-8543-1587.

Cristiane Valle Tovo: 0000-0002-7932-5937.

Sabrina Alves Fernandes: 0000-0001-8504-603X.

Costa DS, Guahnon MP, Seganfredo FB, Pinto LP, Tovo CV, Fernandes AS. Vitamina B12 e homocisteína em pacientes com DHGNA: revisão sistemática e metanálise. Arq Gastroenterol. 2021;58(2):234-9.

RESUMO - Contexto - A absorção de vitamina B12 pode ser afetada em pacientes com doença hepática gordurosa não alcoólica (DHGNA), e baixos níveis séricos de vitamina B12 têm sido relacionados a níveis elevados de homocisteína (HCI) ao grau de DHGNA. Objetivo - Realizar revisão sistemática e metanálise dos níveis séricos de vitamina B12 e de HCI em pacientes com DHGNA. Métodos - Estudos originais que incluíssem avaliação dos níveis séricos de vitamina B12 e de HCI em humanos com DHGNA foram incluídos. As buscas foram realizadas em quatro bases de dados. Resultados - Foram identificados 159 estudos e, após exclusão das duplicatas e dos não elegíveis, oito artigos originais foram incluídos. Seis dos oito artigos

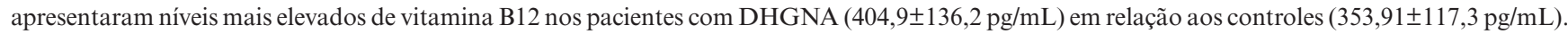
Sete dos oito estudos determinaram os níveis de HCI, estando aumentados em pacientes com DHGNA (14,2 $\pm 3,44$ umol/L) em relação aos controles (11,05 $\pm 3,6$ umol/L). Os resultados dos níveis séricos de vitamina B12 e HCI foram submetidos à metanálise, mostrando que não há diferença nos níveis de vitamina B12 entre os pacientes com DHGNA e os controles. No entanto, os níveis de HCI foram maiores nos pacientes com DHGNA do que nos controles. Conclusão - Não houve relação entre DHGNA e nível sérico de vitamina B12. Os níveis de HCI foram significativamente maiores em pacientes com DHGNA, sugerindo que esse poderia ser um potencial marcador de lesão hepática.

Palavras-chave - Doença hepática gordurosa não-alcoólica; esteato-hepatite não alcoólica; vitamina B12; vitaminas; homocisteina. 


\section{REFERENCES}

1. Chalasani N, Younossi Z, Lavine JE, Diehl AM, Brunt EM, Cusi K, et al. The diagnosis and management of non-alcoholic fatty liver disease: practice Guideline by the American Association for the Study of Liver Diseases, American College of Gastroenterology, and the American Gastroenterological Association. Hepatology. 2012;55: 2005-23.

2. Eslam M, Newsome PN, Anstee QM, Targher G, Gomes MR, et al. A new definition for metabolic dysfunction associated fatty liver disease: an international expert consensus statement. J Hepatol. 2020;73:202-9.

3. Buzzetti E, Pinzani M, Tsochatzis EA. The multiple-hit pathogenesis of non-alcoholic fatty liver disease (NAFLD). Metabolism. 2016;65:1038-48.

4. Scheidt L., Schmidt L., Pinheiro TLF, Benetti F. Nutrição na doença hepática gordurosa não alcoólica e síndrome metabólica: uma revisão integrativa. Arq. Cienc. Saúde 2018;22:129-38.

5. Mahmud M, NaimM, Nicola LB, Kasem S, Yarden Y, Mohammad A, et al. Folate and B12 Levels Correlate with Histological Severity in NASH Patients. Nutrients. 2018;10:440.

6. Sazci A, Akpinar G, Aygun C, Ergul E, Senturk O, Hulagu S. Association of apolipoprotein E polymorphisms in patients with non-alcoholic steatohepatitis. Dig Dis Sci. 2008;53:3218-24.

7. Polyzos SA, Kountouras J, Patsiaoura K, Katsiki E, Zafeiriadou E, Deretzi G, et al. Serum homocysteine levels in patients with nonalcoholic fatty liver disease. Ann Hepatol. 2012;11:68-76.

8. Moretti R, Caruso P, Gazzin S. Non-alcoholic fatty liver disease and neurological defects. Annals Hepatol. 2019;18:563-70.

9. Leach NV, Dronca E, Vesa SC, Sampelean DP, Craciun EC, Lupsor M, et al. Serum homocysteine levels, oxidative stress and cardiovascular risk in non-alcoholic steatohepatitis. Eur J Intern Med. 2014;25:762-7.
10. Kasapoglu B, Turkay C, Yalcin KS, Kosar A, Bozkurt A. MTHFR 677C/T and 1298A/C mutations and non-alcoholic fatty liver disease. Clin Med (Lond). 2015;15:248-51.

11. Hirsch S, Poniachick J, Avendaño M, Csendes A, Burdiles P, Smok G, et al. Serum folate and homocysteine levels in obese females with non-alcoholic fatty liver. Nutrition. 2005;21:137-41.

12. Gulsen M, Yesilova Z, Bagci S, Uygun A, Ozcan A, Ercin CN, et al. Elevated plasma homocysteine concentrations as a predictor of steatohepatitis in patients with non-alcoholic fatty liver disease. J Gastroenterol Hepatol. 2005;20: 1448-55.

13. De Carvalho SC, Muniz MT, Siqueira MD, Siqueira ER, Gomes AV, Silva KA, et al. Plasmatic higher levels of homocysteine in non-alcoholic fatty liver disease (NAFLD). Nutr J. 2013;12:37.

14. Leach NV, Dronca E, Craciun, EC, Crisan, D. High levels of serum homocysteine in non-alcoholic steatohepatitis. Eur J Intern Med. 2016;35:38-9.

15. Dai Y, Zhu J, Meng D, Yu C, Li Y. Association of homocysteine level with biopsyproven non-alcoholic fatty liver disease: a meta-analysis. J Clin Biochem Nutr. 2016;58:76-83.

16. Polyzos SA, Kountouras J, Tsoukas MA. Circulating homocysteine in non-alcoholic fatty liver disease. Eur J Intern Med 2015;26:152-3.

17. Koplay M, Gulcan E, Ozkan F. Association between serum vitamin B12 levels and the degree of steatosis in patients with nonalcoholic fatty liver disease. $\mathbf{J}$ Investig Med. 2011;59:1137-40.

18. Polyzos SA, Kountouras J, Patsiaoura K, Katsiki E, Zafeiriadou E, Zavos C, et al. Serum vitamin B12 and folate levels in patients with non-alcoholic fatty liver disease. Int J Food Sci Nutr. 2012;63 659-66. 